\title{
BADANIA MARKETINGOWE JAKO PODSTAWA PLANOWANIA DZIAŁAŃ I INSTRUMENTÓW MARKETINGOWYCH TOWARZYSZĄCYCH WPROWADZENIU NA RYNEK NOWEGO PRODUKTU (PRZYPADEK NAWOZU FOSFOROWEGO FIRMY STRUGA SA)
}

Zarys treści: W artykule ukazano rolę, jaką w organizacjach działających w zmiennym otoczeniu odgrywają prawidłowo zaplanowane i zrealizowane badania marketingowe. W opisie autorka odwołuje się do badania przeprowadzonego dla Struga SA, którego głównym celem było pozyskanie danych wspierających zarząd firmy w zaprojektowaniu działań i instrumentów marketingowych towarzyszących wprowadzeniu na rynek innowacyjnego nawozu, powstałego z popiołów wytwarzanych w trakcie spalania przyjmowanych przez firmę odpadów pochodzenia zwierzęcego.

S łow a kluc z ow e : marketing; badania marketingowe; marketing-mix; nawóz fosforowy

K las yfikacja JEL: L15; M31; L60

* Adres do korespondencji: Iwona Escher, Uniwersytet Mikołaja Kopernika w Toruniu, Wydział Nauk Ekonomicznych i Zarządzania, Katedra Marketingu i Handlu, ul. Gagarina 13a, 87-100 Toruń, e-mail: escher@umk.pl. 


\section{WSTĘP}

Wyniki wielu analiz prowadzonych na polskim rynku wskazują, że badania marketingowe wciąż pozostają jedną z najbardziej zaniedbywanych sfer działalności marketingowej polskich przedsiębiorstw ${ }^{1}$. Nadal są postrzegane przez znaczną liczbę ich przedstawicieli jako działanie zbędne, będące źródłem dodatkowego obciążenia finansowego. Tymczasem w teorii marketingu wyraźnie podkreśla się, że jedną z podstawowych cech organizacji zorientowanych marketingowo, jak i organizacji zorientowanych rynkowo (tj. organizacji uznawanych niejako za wzorzec, biorąc pod uwagę aktualne uwarunkowania działania firm na rynku ${ }^{2}$ ) jest priorytetowe traktowanie sfery badawczej. To właśnie badania marketingowe winny dziś stanowić w przedsiębiorstwach podstawę podejmowania decyzji dotyczących m.in. przygotowania i zastosowania wszystkich działań i instrumentów oddziaływania na rynek. Innymi słowy, to wyniki badań marketingowych (a nie rutyna czy intuicja właścicieli) winny być punktem wyjścia w procesach decydowania m.in. o tym: jaki produkt winien być oferowany na rynku (zanim jeszcze zostanie on wyprodukowany czy zakupiony w celu dalszej odsprzedaży), jaka powinna być jego cena, który sposób promocji i dystrybucji winien być zaproponowany, aby mógł zapewnić najlepsze dotarcie $\mathrm{z}$ informacją i produktem do docelowego rynku itp. Wymienione obszary decyzji dotyczą znanego z marketingowej literatury zbioru działań i instrumentów marketingowych nazywanego marketingiem-mix. W klasycznej wersji budują go cztery elementy (produkt, cena, dystrybucja, promocja), przy czym wraz ze zmianami uwarunkowań działania organizacji i wynikającymi z nich zmianami celów i sposobów funkcjonowania, zmianie ulega

Por. m.in. grant KBN nr 1 H02D03318 pt. Czynniki kształtujące marketingowa świadomość polskiej kadry kierowniczej oraz stan i rozwój zastosowań marketingu $w$ matych $i$ średnich przedsiębiorstwach oraz grant MNiSW nr N N115 549738 pt. Stan i rozwój marketingu w przedsiębiorstwach funkcjonujących na terenie Polski. Oba granty realizowane były przez pracowników Katedry Marketingu i Handlu WNEiZ UMK w Toruniu. Szczegółowe wyniki z nich pozyskane dostępne są m.in. w: Kaczmarczyk, 2002; Kaczmarczyk, Petrykowska, 2011.

2 Szerzej na temat odmienności pomiędzy organizacjami zorientowanymi marketingowo oraz organizacjami zorientowanymi rynkowo pisze Escher [2009, s. 177-185; 2011b, s. 19-31]. 
samo pojęcie marketing, a z nim także skład marketingu-mix będącego jego integralną częścią ${ }^{3}$.

Coraz większa zmienność warunków działania firm (burzliwość i złożoność zmian) powoduje, że niepewność podejmowania aktywności rynkowej i ryzyko z nią związane rosną. Firmy muszą stale poszukiwać nowych rozwiązań biznesowych, ponieważ w nowych, zmienionych warunkach najlepsza w danym momencie kompozycja działań i instrumentów marketingowych (niezależnie czy definiowana wąsko w postaci 4P, czy też szerzej - por. przypis 3) przestaje być najbardziej właściwa [Garbarski, Rutkowski, Wrzosek, 2000, s. 58-67]. Nie ma lepszego sposobu na zaprojektowanie owej kompozycji, jak tylko wsparcie się wynikami badań marketingowych na etapie jej tworzenia, przy czym pamiętać należy, że samo przeprowadzenie badania nie jest jeszcze gwarantem sukcesu rynkowego nie eliminuje całkowicie ryzyka prowadzenia działalności, automatycznie nie zapewnia też wzrostu sprzedaży i zysku. Jednak jeśli badania są prawidłowo zaprojektowane i rzetelnie zrealizowane, a ich wyniki są właściwie wykorzystane w procesie podejmowania decyzji, można (jak zostanie wykazane w artykule) ryzyko to znacząco zredukować, zwiększając jednocześnie prawdopodobieństwo odniesienia wspomnianego sukcesu rynkowego.

W literaturze marketingowej istnieje wiele definicji badań marketingowych, wiele jest też opisywanych klasyfikacji badań i sposobów ich realizacji ${ }^{4}$. Zagubieni $\mathrm{w}$ gąszczu tych różnych ujęć praktycy, zwłaszcza reprezentujący mikro-, małe i średnie przedsiębiorstwa, często ze strachem podchodzą do idei prowadzenia badań, błędnie zakładając, że tego typu działanie jest zarezerwowane jedynie dla dużych firm, dysponujących du-

3 Szeroki przegląd alternatywnych koncepcji marketingu-mix opisywanych w literaturze marketingowej prezentuje m.in. Constantinides [2006, s. 407-438]. Owe alternatywne koncepcje (w tym najbardziej znane 5P i 7P opisywane m.in. przez Brunera [1989, s. 72-77], Grőnroosa [1994, s. 347-360], Anitsala i in. [2012, s. 77-80]) wyrastają zwykle na krytyce klasycznego (czteroelementowego) ujęcia marketingu-mix (w skrócie opisywanego jako 4P), któremu zarzuca m.in. brak konsekwencji w wyodrębnianiu poszczególnych jego elementów (nieprawidłowe łączenie w jednym zbiorze elementów należących z różnych kategorii), pomijanie niektórych działań, w tym badań marketingowych [Kaczmarczyk, 1999, s. 140-141], nieprzystawalność do aktualnych warunków działania oraz specyfiki określonych typów organizacji, przede wszystkim tych, które funkcjonują na rynku dóbr zaopatrzeniowych i w sektorze usług [van Waterschoot, van den Bulte, 1992, s. 83-93; English, 2000, s. 21-23; Constantinides, 2006, s. 407-438].

4 Różne rodzaje badań w polskiej literaturze marketingowej opisują m.in.: Kaczmarczyk [2007, 2011], Mazurek-Łopacińska [2002], Maison [2010]. 
żym budżetem i personelem wyspecjalizowanym w zakresie marketingu. Nie podejmują badań, nie poszukują też możliwości ich realizacji przez zewnętrznych wykonawców, obawiając się, że koszty zlecenia przerosną ich finansowe możliwości. Dobrym rozwiązaniem na przezwyciężenie tego impasu stają się projekty, których ideą przewodnią jest łączenie przedstawicieli sektora MŚP i ludzi nauki. Niestety, mimo że w Polsce w ostatnich latach pojawiło się ich dużo, niewiele firm do nich przystępuje. Przeszkodą w tej współpracy są nie tylko bariery praktyczne (skomplikowane, pracochłonne aplikowanie; zawiłość językowa dokumentacji itp.), ale też liczne bariery nieformalne - przede wszystkim popularne stereotypy, których ofiarami stają sie obie strony opisywanej relacji ${ }^{5}$.

$\mathrm{Z}$ mylnymi przekonaniami dotyczącymi trudności w realizacji badań marketingowych oraz współpracy przy ich prowadzeniu z przedstawicielami biznesu i nauki zrywa przypadek opisany w niniejszym artykule. Głównym celem artykułu jest wykazanie, na przykładzie badania zrealizowanego dla firmy Struga SA, że badania marketingowe z powodzeniem (korzyścią dla podejmowanych decyzji natury marketingowej) mogą być realizowane także w mniejszych firmach, dysponujących niedużymi budżetami marketingowymi, prowadzących specyficzną działalność rynkową, napotykających charakterystyczne problemy decyzyjne (odbiegające od typowych problemów, z którymi w większości przypadków mają do czynienia badacze marketingowi $)^{6}$, a jedynym warunkiem uzyskania $\mathrm{z}$ tych

5 Naukowiec bywa postrzegany jako osoba o skostniałych poglądach, wiedzy i kwalifikacjach nieprzystosowanych do realnego świata biznesu. Z kolei przedsiębiorca często widziany jest jako osoba niezainteresowana pogłębianiem wiedzy, skoncentrowana jedynie na dążeniu do osiągania zysku [Bariery..., 2006, s. 3-5; Identyfikacja..., 2008, s. 3-19; Dymowski, 2012, s. 2-9; Karwacka, 2012, s. 18-22].

6 Struga SA (http://struga.pl) jest polskim przedsiębiorstwem zajmującym się odbiorem oraz utylizacją odpadów i produktów ubocznych pochodzenia zwierzęcego. Na moment realizacji pomiaru, o którym mowa w artykule, firma posiadała status podmiotu średniego. $Z$ uwagi na swoją specyfikę, nie należy do podmiotów będących typowymi zleceniodawcami badań marketingowych realizowanych w Polsce (a także w innych krajach). Niekwestionowanymi liderami w rankingu zleceniodawców badań marketingowych na polskim rynku (biorąc pod uwagę wielkość wydatków przeznaczanych na ich realizację) są firmy z rynku dóbr szybkozbywalnych (FMCG). Warto przy okazji dodać, że na drugim miejscu w tej klasyfikacji lokuje się w Polsce sektor publiczny. Od 2011 roku wyprzedza (wyżej do tego momentu lokowane) sektory farmaceutyków i produktów medycznych oraz sektory telekomunikacji i mediów elektronicznych [Katalog PTBRiO 2007, s. 10; Katalog PTBRiO 2010/2011, s. 16; Rocznik PTBRiO 2012/2013, s. 26; Rocznik PTBRiO 2013/2014, s. 36]. 
badań danych o wysokiej jakości jest prawidłowe ich zaplanowanie przy nienagannej współpracy badacza i zleceniodawcy (także wtedy, gdy przebiega ona na linii nauka-biznes), a następnie ich realizacja w absolutnej zgodzie z uprzednio przyjętym projektem.

Pomocne w realizacji opisanego celu będą wpisujące się w problematykę opracowania dostępne $\mathrm{w}$ literaturze $\mathrm{z}$ zakresu marketingu, $\mathrm{w}$ tym zwłaszcza badań marketingowych, wnioski z badania prowadzonego dla firmy Struga SA, a także doświadczenia autorki wyniesione przy realizacji innych projektów badawczych (cel artykułu nie uwzględnia prezentowania szczegółowych danych pozyskanych z badania prowadzonego dla Struga $\mathrm{SA}$ - te, z uwagi na tajemnicę firmy, nie mogą być bowiem ujawnione).

\section{KLUCZOWE ETAPY PLANOWANIA I REALIZACJI BADANIA MARKETINGOWEGO}

Na rysunku 1 zaprezentowano uniwersalną ścieżkę (niezależną od tematyki badania), którą winna przebyć osoba decydująca się na zaprojektowanie (a następnie realizację) marketingowego badania pierwotnego o charakterze fragmentarycznym (ten rodzaj badania jest najczęściej spotykany w praktyce marketingowej, ponieważ ograniczenia czasowe, finansowe lub organizacyjne nie pozwalają zwykle na wybór badań pełnych, korzystniejszych z punktu widzenia jakości pozyskiwanych danych, a niska wiarygodność wielu źródeł wtórnych, ich nieodpowiedniość, nieaktualność, niekompletność bądź niedostępność ogranicza możliwość prowadzenia badań wtórnych, mimo że w porównaniu z badaniami pierwotnymi zwykle są tańsze, łatwiejsze i szybsze w realizacji).

Bodźcem do podjęcia badań jest zawsze problem decyzyjny, przed którym staje osoba zarządzająca $\mathrm{w}$ organizacji i którego nie jest w stanie rozwiązać bez wsparcia informacyjnego. Pierwszą czynnością podejmowaną przez badacza $w$ fazie projektowania badania winno być przekształcenie owego problemu decyzyjnego w problem badawczy. Złe jego przełożenie (a także niepoprawne zdefiniowanie na jego podstawie celów i hipotez badawczych) może spowodować, że uzyskane wyniki okażą się nieużyteczne z punktu widzenia potrzeb informacyjnych decydenta lub też doprowadzą do podjęcia błędnej decyzji .

7 Przykładową procedurę przekształcenia problemu decyzyjnego $\mathrm{w}$ problem badawczy, obejmującą także definiowanie celów badania i powiązanych z nimi hipotez, prezentuje Escher [2011a, s. 110-111]. 
Nie ma możliwości trafnego zdefiniowania problemu badawczego bez dogłębnego rozpoznania problemu decyzyjnego zleceniodawcy. Realizacja opisanych czynności rozpoczynających projektowanie badania w praktyce bywa często pomijana lub robiona w pośpiechu (z racji braku czasu lub niechęci zleceniodawców do ujawniania wybranych informacji o swojej działalności), tymczasem jest ona kluczowa z punktu widzenia wartości danych pozyskiwanych w badaniu (problem badawczy, a wraz z nim cele i hipotezy badawcze wyznaczają bowiem kierunek działań podejmowanych przez badacza na wszystkich kolejnych etapach tego procesu).

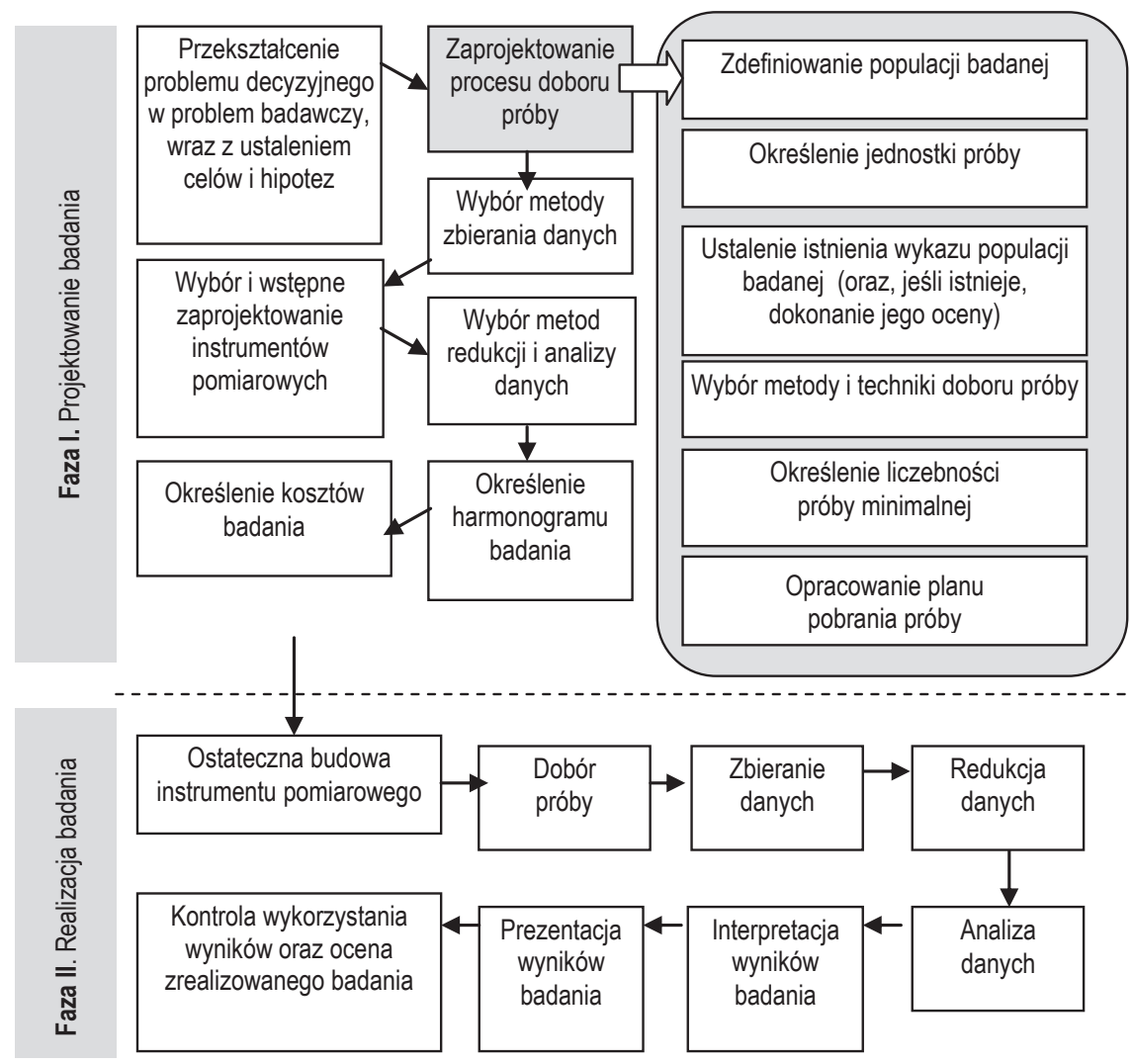

Rysunek 1. Główne etapy procesu badawczego w sytuacji, gdy badacz decyduje się na realizację badania fragmentarycznego, wykorzystując pierwotne źródła informacji

Źródło: opracowanie własne na podstawie: Escher [2011a, s. 108-118], Kaczmarczyk [2011, s. 48]. 
Jeżeli badanie nie może mieć charakteru pełnego, niezbędnym etapem jego projektowania jest tzw. zaprojektowanie procesu doboru próby. W jego ramach konieczne staje się m.in. wskazanie odpowiedniej metody doboru jednostek próby oraz określenie jej liczebności. Wielu niewprawionych badaczy, niezależnie od problemu badawczego, wpisuje do projektu dobór losowy, mimo że nie zawsze możliwe jest pozyskanie lub stworzenie prawidłowego wykazu badanej populacji, niezbędnego do przeprowadzenia takiego doboru ${ }^{8}$. Pogłębiając swój błąd, arbitralnie określają liczebność „losowo dobieranej” próby (mimo że w przypadku doboru losowego winna być ona ustalona przez zastosowanie specjalnych wzorów ${ }^{9}$ ), a co gorsze, na etapie analizy dane pozyskane z pomiaru tak wybranej i ustalonej próby traktują jakby pochodziły z próby losowej, wnioskując na ich podstawie w sposób nieuprawiony o kształtowaniu się parametrów całej populacji.

Innym, kluczowym (z punktu widzenia jakości pozyskiwanych danych) etapem projektowania każdego procesu badawczego jest wybór metody zbierania danych. Zawsze winien być on dokonywany przy uwzględnieniu rodzaju potrzebnych danych, cech jednostek badania oraz wad i zalet wszystkich dostępnych metod pomiaru. Nie ma jednej idealnej metody zbierania danych dla wszystkich problemów badawczych i wszystkich jednostek badania. Analogicznie, nie ma też jednego, uniwersalnego instrumentu pomiarowego dla wszystkich procesów badawczych ${ }^{10}$. Wybór

8 Prawidłowy wykaz populacji powinien być przede wszystkim: kompletny, aktualny i dokładny (tzn. winien uwzględniać na moment jego wykorzystania wszystkie jednostki interesującej badacza populacji; nie powinien zawierać jednostek spoza populacji lub takich, które powinny z niej już być wykreślone; każda jednostka populacji winna pojawić się w nim tylko raz) [Kaczmarczyk, 20011, s. 96].

9 We wzorach tych jeszcze na etapie planowania procesu doboru ustala się: dopuszczalny błąd, z jakim badacz będzie wnioskował na podstawie wyników z próby o kształtowaniu się parametrów w populacji (tzw. dokładność estymacji), oraz prawdopodobieństwo (tzw. poziom ufności), z jakim będzie mógł orzekać o tym, że ustalony przez niego przedział ufności zawierać będzie poszukiwaną wartość szacowanego parametru populacji - por. m.in. [Brzeziński, 1984, s. 137-143; Mynarski, 2000, s. 35-67; Szewczyk, Ciesielska, 2000, s. 105-109; Churchill, 2002, s. 545-562; Rószkiewicz, 2002, s. 62-74; Szreder, 2010, s. 106-149; Kaczmarczyk, 2011, s. 86-90].

10 Każdej metodzie odpowiadają konkretne instrumenty pomiarowe. Niektóre mogą być wykorzystywane w wielu metodach zbierania danych (np. wzrok jako instrument naturalny w metodzie obserwacji, ale też przy studiowaniu źródeł wtórnych czy degustacjach, nazywanych zamiennie metodami sensorycznymi lub organoleptycznymi); inne z kolei są charakterystyczne tylko dla konkretnej metody (np. tachistoskop wykorzystywany w pomiarach fizjologicznych). Najbardziej popularne metody zbie- 
instrumentu pomiarowego, a także jego konstrukcja każdorazowo wynikać powinny z wybranej metody zbierania danych ${ }^{11}$. Źle dobrany lub źle zbudowany instrument (tak samo jak źle dobrana metoda zbierania danych) jest źródłem poważnych błędów, obniżających wiarygodność danych pozyskiwanych w badaniu. Sposobem na ich uniknięcie lub redukcję jest badanie pilotażowe, prowadzone przed przystąpieniem do badania właściwego. Niedoświadczeni badacze pomijają jego realizację, głównie z uwagi na niedostrzeganie jego istotnej roli w procesie badawczym i mylne stereotypowe opinie na jego temat ${ }^{12}$. W jego trakcie sprawdzeniu podlegają wszystkie istotne założenia przyjęte $\mathrm{w}$ projekcie badania, a zatem nie tylko zaproponowany instrument (jego postać), ale też: poprawność przyjętych ustaleń dotyczących procesu doboru próby, adekwatność zaproponowanej metody pomiaru, instrumentu oraz metod redukcji i analizy danych do celów badania oraz postawionych hipotez. Dopiero po zakończeniu badania pilotażowego możliwe jest zakończenie etapu projektowania badania, tj. opracowanie jego harmonogramu i kosztorysu. Dzięki opisaniu w nich ciągu czynności, które należy wykonać przy wskazanych środkach, zaplanowany proces badawczy przebiegać może sprawnie, zapewniając realizację założonych celów w przewidzianym czasie i w obrębie założonego budżetu.

Przejście do fazy realizacji badania winno następować dopiero po zaakceptowaniu przez zleceniodawcę propozycji badawczych zawartych w projekcie. Badacz dokonuje wówczas (uwzględniając wnioski z badania pilotażowego) ostatecznej budowy instrumentu pomiarowego. Dobiera także jednostki próby (zależnie od wybranej metody pomiaru oraz me-

rania danych i stosowane w ich ramach instrumenty pomiarowe wraz ich klasyfikacją prezentuje m.in. Kaczmarczyk [2011, s. 68-69].

11 Powszechnym błędem popełnianym przez wielu badaczy jest nieodróżnianie metody zbierania danych i stosowanego w jej ramach instrumentu pomiarowego (np. przy opisie metody ankietowej piszą o „wysyłaniu ankiety”, a przy opisie wywiadu osobistego - o odpowiadaniu przez respondentów na ,pytania ankiety”). Ankieta jest metodą zbierania danych. Towarzyszy jej instrument nazywamy kwestionariuszem ankietowym. Wypełnia się i wysyła kwestionariusz ankietowy, a nie ankietę. Ankiety (metody) wysłać nie można, tak samo jak nie można jej wypełnić. Analogicznie, metodą zbierania danych jest wywiad osobisty. Stosuje się w nim instrument pomiarowy nazywany kwestionariuszem wywiadu. To w tym instrumencie zapisane są pytania do respondenta odczytywane przez ankietera. W żadnym wypadku nie można powiedzieć, że instrumentem tym jest ankieta [Escher, 2011a, s. 124-125].

12 Jest często postrzegane jako obciążenie organizacyjne i finansowe, mimo że nie wymaga prowadzenia pomiarów na dużej próbie i w długim czasie - por. m.in. [Kaczmarczyk. 2011, s. 162-163]. 
tody i techniki doboru jednostek, dobór ten odbywać się może przed lub równolegle z kolejnym etapem, jakim jest zbieranie danych). Pozyskane z pomiaru dane badacz analizuje i interpretuje. Warto jednak pamiętać, że w pierwszej kolejności dane te powinien poddać redukcji. W jej ramach winien m.in.: sprawdzić poprawność zrealizowanego pomiaru (np. w badaniach z udziałem ankieterów - dokonać oceny przeprowadzonego przez nich procesu doboru jednostek $\mathrm{w}$ terenie oraz kompletności zebranych przez nich danych itp.) oraz dokonać tzw. redakcji danych ( $\mathrm{tj}$. naniesienia do pozyskanych danych niezbędnych poprawek i uzupełnień, tam gdzie trzeba i gdzie można to uczynić z uwagi na ich wzajemne wykluczanie się, niekompletność, niejednoznaczność lub nieadekwatność). Opracowane wyniki badania (wraz z wnioskami i zaleceniami dla decydentów, jeśli takie jest ich oczekiwanie) standardowo przekazuje się w postaci pisemnej (raport z badania) $)^{13}$.

Przygotowanie raportu nie powinno jednak kończyć procesu badawczego. Badacz winien pomagać decydentowi w zrozumieniu prezentowanych w raporcie wyników (upewniając się, że poprawnie je interpretuje), śledzić, w jaki sposób zostały one rzeczywiście wykorzystane, i jeśli to możliwe wspomagać $\mathrm{w}$ ich zastosowaniu czy sugerować korektę postępowania. Dzięki temu ma on również możliwość dokonania oceny zrealizowanego procesu badawczego. Wspomniana ocena badania jest ważnym etapem kończącym każdy proces badawczy. W jej ramach dochodzi bowiem do ustalenia, jakie korzyści osiągnięto dzięki wykorzystaniu wyników badania i czy korzyści te były adekwatne do poniesionych kosztów (z reguły trudno je jednak zmierzyć ilościowo, stąd ich ocena jest zwykle jakościowa i opiera się na ocenie tego, na ile pozyskane dane okazały się przydatne w procesie podejmowania decyzji, ograniczając niepewność działania firmy). Podobnie jak w przypadku fazy koncepcyjnej, zaniedbania badacza bądź jego błędy poczynione na jakimkolwiek etapie fazy realizacji pomiaru $^{14}$ skutkować będą obniżeniem wiarygodności pozyskanych danych

13 Raport jest materialnym rezultatem prac badawczych, na którym w dużej części lub całkowicie opierają się decyzje zleceniodawcy. Jest też podstawą oceny jakości pracy badacza, stąd tak wiele uwagi w literaturze marketingowej poświęca się zasadom jego przygotowania - por. m.in. [Churchill, 2002, s. 855-885; Hague, 2002, s. 283-324; Kaczmarczyk, 2011, s. 447-458].

14 Np. wadliwa budowa instrumentu pomiarowego, pobranie w terenie niewłaściwych jednostek, realizacja pomiaru niezgodnie z przyjętą metodą, niestaranne przygotowanie danych surowych do analizy, zastosowanie nieodpowiednich metod analizy, pomyłki w obliczeniach, błędy interpretacyjne wynikające z niezrozumienia wyników 
i ich przydatności w procesie podejmowania decyzji (błędy popełnione na etapie projektowania i realizacji badania, niezależnie od odmienności ich nazywania i klasyfikowania przez poszczególnych badaczy, składają się na łączny błąd badania obniżający jakość pozyskanej informacji [Mynarski, 2000, s. 69-74; Sierra Bravo, 2008, s. 213-215; Szreder, 2010, s. 170-183; Kaczmarczyk, 2011, s. 55-63]).

\section{FAZA KONCEPCY JNA I FAZA REALIZACJI POMIARU W BADANIU DLA STRUGA SA}

Badanie, o którym mowa $\mathrm{w}$ tytule tej części, prowadzono od marca do kwietnia 2012 roku (przy czym prace koncepcyjne, zmierzające do stworzenia projektu tego badania, rozpoczęły się niemal dwa miesiące wcześniej). Miało ono charakter pierwotnego badania fragmentarycznego ${ }^{15}$. Dzięki właściwemu jego zaplanowaniu, a następnie konsekwentnej realizacji zgodnie $\mathrm{z}$ opisem przedstawionym $\mathrm{w}$ poprzedniej części, pozyskano w nim dane, które okazały się wysoce użyteczne z punktu widzenia potrzeb informacyjnych zarządu Struga SA (por. dalsza część).

Bezpośrednim impulsem do realizacji badania były problemy decyzyjne zarządu związane z planami poszerzenia profilu dotychczas realizowanej działalności o produkcję i sprzedaż nawozu fosforowego, powstałego $\mathrm{z}$ popiołów wytwarzanych $\mathrm{w}$ trakcie spalania przyjmowanych przez firmę odpadów zwierzęcych. Firma od kilku lat prowadziła prace nad opracowaniem i wdrożeniem technologii zagospodarowania oraz odzysku owych popiołów, stanowiły one bowiem istotny problem logistyczno-ekonomiczny i ekologiczny. Opracowana procedura wytwarzania nawozu (mająca dodatkowo charakter bezodpadowy) okazała się przedsięwzięciem unikatowym w skali światowej (popioły pozostające po spaleniu odpadów pochodzenia zwierzęcego nie były nigdy wcześniej wykorzystywane jako surowiec nawozowy). Badania laboratoryjne wykazały, że powstały z popiołów nawóz

analizy, świadome zniekształcanie tych wyników dla wykazania słuszności uprzednio postawionych hipotez, niewłaściwe zaprezentowanie wyników badania decydentowi itp.

15 Badanie realizowane było przez autorkę podczas sześciomiesięcznego stażu w Struga SA w ramach projektu pn. Staż sukcesem naukowca (projekt realizowany przez PAIP ze środków UE w ramach EFS, Priorytet VIII: Regionalne kadry gospodarki, Działanie 8.2. Transfer wiedzy, Poddziałanie: 8.2.1: Wsparcie dla współpracy sfery nauki i przedsiębiorstw). 
ma parametry pożądane z punktu widzenia wymogów rolnictwa. Był jednocześnie produktem w pełni naturalnym, co stwarzało możliwości jego stosowania w rolnictwie ekologicznym. Podjęte w firmie prace nad wdrożeniem opracowanej technologii zbliżyły ją do etapu komercjalizacji nawozu. Zarząd firmy był jednak świadomy, że samo posiadanie produktu odznaczającego się bardzo dobrymi parametrami nie gwarantuje osiągnięcia sukcesu na rynku, a w konsekwencji, że decyzje co do wytwarzanej ostatecznie jego formy fizycznej (pylista lub granulowana ${ }^{16}$ ) oraz działań i instrumentów marketingowych towarzyszących jego sprzedaży nie mogą być podjęte $\mathrm{z}$ pominięciem badań marketingowych pozwalających rozpoznać potrzeby i preferencje jego potencjalnych nabywców ${ }^{17}$.

Zgodnie $\mathrm{z}$ opisaną $\mathrm{w}$ poprzedniej części procedurą, pierwszym zadaniem badacza było właściwe sformułowanie problemu badawczego oraz powiązanych $\mathrm{z}$ nim celów badania ${ }^{18}$ i hipotez badawczych (czynności te poprzedziło dogłębne rozpoznanie problemu decyzyjnego firmy, specyfiki prowadzonej przez nią działalności oraz charakterystyki produktu planowanego do wprowadzenia na rynek). Stały się one punktem wyjścia do zaprojektowania pozostałych czynności w fazie koncepcyjnej badania (za-

16 Opracowana w firmie technologia dawała możliwość wytwarzania nawozu w tych dwóch postaciach.

17 Taki sposób podejścia do procesu tworzenia produktu i jego komercjalizacji (a zwłaszcza wykorzystania w tych procesach danych pozyskanych z badań marketingowych) jest jedną z podstawowych cech organizacji zorientowanych marketingowo oraz organizacji zorientowanych rynkowo, a jednocześnie wyrazem wysokiej świadomości marketingowej decydentów tych organizacji. Niestety, jak wskazują wyniki badań, w przypadku wielu przedsiębiorstw działających na polskim rynku (zwłaszcza z sektora MŚP) nadal poziom owej świadomości nie jest wysoki - por. m.in. Escher [2011c, s. 50-60].

18 Uwzględniając potrzeby informacyjne decydentów, zaproponowano trzy główne cele badania: (1) ustalenie podstawowych charakterystyk procesu zakupu nawozów (w tym nawozów fosforowych) realizowanego na polskim rynku nawozowym przez klientów finalnych; (2) identyfikację głównych konkurentów dla wprowadzanego przez Struga SA produktu nawozowego; (3) oszacowanie stopnia zainteresowania nowym produktem firmy Struga SA w grupie potencjalnych jego nabywców; a także $d w a$ cele dodatkowe, zakładające kolejno: (1) rozpoznanie rodzaju ustosunkowania się respondentów wobec nawozów naturalnych typu Eko oraz (2) ustalenie stopnia, w jakim nowy produkt, zdaniem osób badanych, pasuje do prowadzonego do tej pory przez Struga SA profilu działalności (cel wprowadzony z uwagi na charakter próby badanej, o której szerzej dalej w artykule). 
projektowania procesu doboru próby, zaproponowania metody zbierania danych, wyboru odpowiedniego instrumentu pomiarowego itp.).

Warunkiem minimalizacji wielu cząstkowych błędów badania, a tym samym osiągnięcia w badaniu wyniku prawdziwego, jest realizacja działań badawczych w absolutnej zgodzie z uprzednio przyjętym projektem [Kaczmarczyk, 2011, s. 55]. To oznacza, że (z punktu widzenia jakości pozyskiwanych danych) ważne jest nie tylko właściwe zaprojektowanie wszystkich czynności fazy koncepcyjnej, ale także ścisłe trzymanie się przyjętych założeń w fazie realizacji badania. Powyższe zalecenie uwzględniono także $\mathrm{w}$ przypadku badania, o którym mowa w artykule. W fazie jego realizacji ściśle przestrzegano założeń badawczych opracowanych w projekcie. $\mathrm{W}$ pomiarze, zgodnie $\mathrm{z}$ ustaleniami, poddano pomiarowi dotychczasowych klientów Struga SA (osoby korzystające z usług utylizacyjnych), którzy prowadzili jednocześnie uprawę roślin. Zrealizowana próba nie była duża (60 respondentów), a jednocześnie nie miała charakteru losowego (zastosowano dobór celowy). Nie oznacza to jednak, że pozyskanych danych nie można było uznać za wartościowe z punktu widzenia zaistniałego w Struga SA problemu decyzyjnego. Zaproponowana metoda doboru próby oraz jej liczebność stanowiły bowiem kompromisowe rozwiązanie pomiędzy: idealną sytuacją z punktu widzenia metodyki badań marketingowych, realnymi możliwościami zleceniodawcy, jego oczekiwaniami a zakładaną naturą prowadzonego badania (zgodnie z założeniami miało mieć ono charakter eksploracyjny, a zatem niewymagający zastosowania doboru losowego ${ }^{19}$ ). Przy takim rozwiązaniu nie było wprawdzie możliwe generalizowanie pozyskanych danych na całą populację (na wszystkie gospodarstwa prowadzące uprawę roślin w Polsce), jednak zdobyto wiedzę, którą można było uznać za dokładną w zakresie tej grupy jednostek, która została objęta badaniem, a to w rozważanym przypadku było o tyle ważne, że jednostkami dobieranymi celowo nie były przypadkowe osoby, lecz te, które zgodnie z opracowaną w Struga SA wstępną koncepcją stanowiły de facto, także z punktu widzenia ilościowego, rynek docelowy dla wprowadzanego nawozu $^{20}$.

19 W badaniach eksploracyjnych bardziej niż na liczby, które mogłyby obrazować interesujące badacza problemy, zwraca się uwagę na lepsze ich rozpoznanie, a także znajdowanie pierwszych pomysłów na ich wyjaśnienie czy rozwiązanie.

20 Z uwagi na ograniczenia w zakresie możliwego do wytworzenia wolumenu produkcji nawozu (rocznie nie więcej niż 2,5-3 tys. ton), a także potencjalnie wysokich kosztów jego dowozu do punktów sprzedaży, firma nie była zainteresowana po- 
W procesie zbierania danych wykorzystano metodę standaryzowanego wywiadu osobistego (metoda bezpośredniego pomiaru sondażowego, należąca do grupy ilościowych metod zbierania danych ze źródeł pierwotnych). Wydawała się ona najwłaściwsza z punktu widzenia możliwości finansowych i organizacyjnych Struga SA oraz wstępnie nakreślonej charakterystyki potencjalnych respondentów i sposobu ich pozyskiwania. Instrumentem pomiarowym był kwestionariusz wywiadu osobistego (wraz $\mathrm{z}$ towarzyszącymi materiałami wspomagającymi ${ }^{21}$ ). Prace prowadzące do stworzenia jego ostatecznej wersji przebiegały stopniowo, w zgodzie ze standardami obowiązującymi w praktyce badań marketingowych. Przyjęły postać wieloetapowego procesu budowy instrumentu pomiarowego, wzorowanego na koncepcji Kaczmarczyka [2011, s. 136-139]. Jednym z jego etapów było testowanie pierwotnej wersji kwestionariusza w ramach wspomnianego w poprzedniej części badania pilotażowego. Ankieterami w pomiarze próbnym, jak i właściwym byli przedstawiciele handlowi Struga SA, którzy jeszcze przed realizacją pomiaru zostali odpowiednio przeszkoleni ${ }^{22}$. Dzięki przydzieleniu im roli ankietera, firmie udało się ograniczyć koszty badania (brak konieczności zatrudnienia osób zewnętrznych), a jednocześnie wzmocnić wśród osób badanych pozytywny wizerunek organizacji (spotkania odbyte $\mathrm{w}$ trakcie pomiaru sprzyjały zacieśnieniu z nimi relacji oraz dostarczyły im psychologicznej satysfakcji, powstałej na skutek podkreślenia ich istotnej roli w procesie poszukiwania rozwiązań dla powstałego w Struga SA problemu decyzyjnego).

Dane uzyskane od respondentów poddano, zgodnie z procedurą wskazaną na rysunku 1, redukcji, analizie statystycznej (na poziomie szczegó-

zyskiwaniem dla niego dużej liczby drobnych, terytorialnie rozproszonych klientów. Wykorzystując dobre relacje, które miała z klientami swoich usług utylizacyjnych, i jednocześnie dostrzegając fakt prowadzenia przez wielu z nich upraw roślin, zakładała, że przy zaoferowaniu korzystnych warunków zakupu, zgłoszony przez nich popyt wyczerpie w całości roczną (możliwą do zaoferowania) podaż nawozu [Escher, 2012a, s. 8].

21 Wśród nich znalazły się m.in. dwie próbki innowacyjnego nawozu firmy (w postaci pylistej i granulowanej), zapakowane w przezroczyste woreczki umożliwiające respondentom dokonanie wszechstronnej oceny produktu.

22 Szkolenie ankieterów (zwłaszcza w przypadku wywiadu osobistego) istotnie determinuje jakość danych pozyskiwanych w pomiarze. Ankieterzy winni być dogłębnie zapoznani z celami prowadzonego badania oraz z przyjętymi rozwiązaniami z zakresu jego metodyki. Powinni wiedzieć, jakie konkretnie czynności muszą w trakcie pomiaru realizować i w jaki sposób jakość ich wykonania wpływa na powodzenie całego projektu. 
łowości i w przekrojach wynikających z celów badania) oraz interpretacji. Następstwem podjętych czynności stało się przygotowanie raportu z badania [Escher, 2012a]. Jego przekazanie zarządowi firmy nie zakończyło procesu badawczego. Badacz miał możliwość wglądu w sposób wykorzystania w firmie wyników badania, a także (po upływie stosownego czasu) dokonania oceny korzyści, jakie osiągnięto w Struga SA dzięki jego realizacji. Na podstawie owej oceny uznać można, że opisane badanie spełniło zakładane w nim cele. Mimo że miało charakter eksploracyjny, z próbą dobraną w sposób celowy, w jego trakcie uzyskano całe bogactwo danych, które pozwoliły decydentom firmy m.in. lepiej rozpoznać zjawiska rynkowe, w dużym stopniu do czasu badania im nieznane (z racji odmiennego profilu prowadzonej działalności).

W ramach pierwszego głównego celu badania (wszystkie cele wymieniono w przypisie 18) zidentyfikowano m.in.: (1) typy nawozów (rodzaje, nazwy) stosowanych w gospodarstwach rolnych badanych osób w ciągu ostatniego półtora roku poprzedzającego moment realizacji pomiaru; (2) miesiące szczególnego nasilenia zakupu tych nawozów; (3) główne źródła informacji, z których badani czerpali wiedzę na temat nawozów dostępnych na rynku oraz (4) główne czynniki decydujące o wyborze spośród nich konkretnego produktu. W ramach drugiego głównego celu badania udało się m.in.: (1) określić stopień znajomości wśród respondentów oferty nawozów fosforowych (ich nazw) dostępnych na polskim rynku; (2) zidentyfikować nazwy nawozów fosforowych dostępnych na polskim rynku uznawanych przez respondentów za najlepsze (a zatem nawozów, które na czas pomiaru można było uznać za główną konkurencję dla nowego produktu Struga SA), oraz (3) zidentyfikować podstawowe ich zalety i mankamenty. W ramach trzeciego głównego celu badania udało się m.in. ustalić wielkość planowanych lub zrealizowanych przez respondentów w 2012 roku (w całości/częściowo) zakupów jakiegokolwiek nawozu fosforowego (zakładając, że nowy produkt firmy spotkałby się z ich zainteresowaniem, uzyskane wielkości można było traktować jako pewnego rodzaju zapowiedź co do rozmiarów przyszłych ich zamówień składanych w Struga SA). Dodatkowo, dzięki specjalnie przygotowanemu pytaniu (wraz z towarzyszącą mu kartą), w ramach którego respondentom pokazano opis czterech hipotetycznych nawozów fosforowych w celu ich uszeregowania od tego, który spełniałby w największym stopniu ich oczekiwania, aż do tego, który te oczekiwania spełniałby w stopniu najmniejszym (cztery hipotetyczne nawozy zostały opisane pod względem: formy fizycznej, wymaganej częstotliwości nawożenia, czasu, na jaki wystarcza zastosowanie nawozu, ceny za tonę), 
udało się stworzyć obraz idealnego nawozu fosforowego, tzn. takiego, który (gdyby pojawił się na rynku) mógłby w największym stopniu spełnić ich oczekiwania. Uzyskane wyniki stanowiły podpowiedź, w którym kierunku Struga SA winna rozwijać swój produkt w zakresie wszystkich rozpatrywanych w pytaniu aspektów nawozów hipotetycznych, ukazując jednocześnie, na ile aktualne parametry jej własnego nawozu pokrywają się z parametrami nawozu uznanego przez respondentów za idealny. Dopełnieniem pozyskanych danych były odpowiedzi respondentów uzyskane w trakcie prezentacji próbek nowego nawozu w dwóch postaciach (pylistej oraz granulowanej). W ramach trzeciego celu głównego udało się także ustalić (na bazie propozycji przygotowanych w firmie) nazwę marki produktu postrzeganą przez respondentów jako najbardziej adekwatną dla przygotowywanego nawozu (a w konsekwencji możliwą do zastosowania przy jego sprzedaży), a także najbardziej atrakcyjny slogan reklamowy, który mógłby towarzyszyć prowadzonym działaniom promocyjnym ${ }^{23}$. Dzięki pytaniom nawiązującym do dwóch celów dodatkowych udało się: (1) rozpoznać kierunek ustosunkowania się badanych osób do naturalnych nawozów typu Eko (poznanie owego ustosunkowania stanowiło istotną wskazówkę odnośnie do tego, czy i jeśli tak, to w jakim stopniu firma powinna akcentować w prowadzonych przez siebie działaniach promocyjnych naturalne pochodzenie nawozu), a także (2) ustalić, na ile, zdaniem osób badanych, nowy produkt pasuje do prowadzonego do tej pory przez Struga SA profilu działalności ${ }^{24}$.

Zebrane dane w znaczący sposób wsparły zarząd Struga SA w podjęciu ważnych decyzji natury marketingowej dotyczących wprowadzanego na rynek nawozu fosforowego (w tym m.in. w zakresie wyboru nazwy jego marki i sloganu reklamowego, działań i instrumentów promocyjnych towarzyszących jego sprzedaży, ceny rynkowej, oferowanych wielkości

23 Żadna z testowanych propozycji nazwy i hasła reklamowego nie funkcjonowała wcześniej w przekazach promocyjnych firmy i żadna też nie była a priori postrzegana w firmie jako preferowana.

24 Przypomnieć należy, że to właśnie osoby badane, będące aktualnymi klientami firmy w zakresie usług utylizacyjnych, były (z uwagi na ograniczenia co do wielkości produkcji nawozu) zakładanym rynkiem docelowym dla nowego produktu. Istniała realna obawa, że wraz z poszerzeniem profilu działalności, firma może utracić w oczach tych osób wizerunek zaufanego kontrahenta w zakresie usług utylizacyjnych lub że jej dobry wizerunek w zakresie dotychczas prowadzonej działalności sprawi, iż będzie postrzegana jako niekompetentna w nowym obszarze aktywności rynkowej (tj. jako producent nawozu fosforowego). 
opakowań, form zakupu i warunków płatności; opisu produktu stosowanego w materiałach sprzedażowych itp.). Eksploracyjny charakter badania oraz mała próba dobierana w sposób nielosowy nie pozwalały jednak na podjęcie decyzji rozstrzygających. $\mathrm{W}$ ich powzięciu decydenci wpierać się musieli dodatkowymi badaniami i pozyskanymi z nich danymi. Przy opracowywaniu formuły produktu (jeszcze przed opisywanym badaniem marketingowym) w szerokim zakresie prowadzone były chociażby badania laboratoryjne (realizowane m.in. przez biotechnologów, mikrobiologów, ekspertów z zakresu gleboznawstwa czy ochrony gleb). Z kolei po zakończonym badaniu marketingowym przy ustalaniu ostatecznych parametrów nawozu wsparto się dodatkowo zaawansowanymi analizami statycznymi m.in. zastosowano metodę oceny wielokryterialnej, dzięki której okazało się, że najbardziej atrakcyjny dla potencjalnych klientów jest najtańszy wariant nawozu, nawet mimo tego, że miał on (jak sugerowały cząstkowe wyniki przeprowadzonego badania marketingowego) mniej preferowaną przez respondentów formę pylistą [Escher, Łapińska, 2014]. Dopiero po wyborze ostatecznej wersji produktu (jego postaci fizycznej oraz pozostałych kluczowych parametrów czyniących produkt atrakcyjnym dla potencjalnych klientów i odmiennym na tle produktów konkurencji) możliwe było zaproponowanie konkretnych rozwiązań w zakresie pozostałych elementów marketingu-mix. Opisany przypadek pokazuje zatem, że warunkiem podjęcia trafnych decyzji natury marketingowej jest nie tylko umiejętne zaplanowanie i zrealizowanie konkretnego badania marketingowego, ale też właściwe łączenie pozyskanych z niego danych z danymi uzyskiwanymi równolegle z innych badań i źródeł ${ }^{25}$.

\section{PODSUMOWANIE}

Dzięki właściwemu zintegrowaniu danych pozyskanych w badaniu marketingowym (opisanym w artykule) z danymi pozyskanymi z innych źródeł,

25 Sięganie po różnorodne źródła informacji i ich łączenie przy podejmowaniu ważnych decyzji (nie tylko natury marketingowej) jest już dziś powszechną praktyką na wielu rynkach, także w Polsce. Realizowane projekty badawcze coraz częściej mają charakter wielowymiarowy i wieloźródłowy (odchodzi się w nich od prostych schematów metodycznych, opartych na wykorzystaniu tylko jednej metody czy źródła informacji), dzięki czemu w sposób bardziej pogłębiony i systemowy (nieoparty jedynie na analizie deklaracji obecnych czy potencjalnych klientów) można spojrzeć na badane kwestie [Marciniak, 2006, s. 14-16]. 
zarząd Struga SA dokonał nie tylko wyboru ostatecznego wariantu nawozu, ale też opracował skuteczną (jak pokazała przyszłość) koncepcję działań i instrumentów marketingowych wykorzystywanych przy jego sprzedaży. Innowacyjny nawóz wraz z towarzyszącymi mu rozwiązaniami marketingowymi został wprowadzony na rynek w 2012 roku $^{26}$. Do dziś pozostaje w ofercie firmy, zapewniając satysfakcjonujące wyniki sprzedażowe (całość jego produkcji znajduje odbiorców) oraz wizerunkowe. Firma pozbyła się istotnego problemu związanego z zagospodarowaniem popiołów powstających w trakcie spalania przyjmowanych odpadów zwierzęcych, nie tracąc jednocześnie wizerunku zaufanego kontrahenta $\mathrm{w}$ zakresie usług utylizacyjnych. Dodatkowo, zyskała wizerunek firmy innowacyjnej, wsłuchującej się w potrzeby rynku, a także działającej w sposób społecznie zaangażowany i odpowiedzialny.

Opisane badanie dowiodło, że badania marketingowe nie są zarezerwowane jedynie dla dużych firm i rynku masowych dóbr konsumpcyjnych. Z powodzeniem (z korzyścią dla podejmowanych decyzji natury marketingowej) mogą być realizowane w mniejszych firmach, prowadzących specyficzną działalność rynkową, dysponujących niedużymi budżetami marketingowymi. Jedynym warunkiem uzyskania danych o wysokiej jakości jest prawidłowe ich zaplanowanie przy nienagannej współpracy badacza i zleceniodawcy (także wtedy, gdy przebiega ona na linii nauka-biznes), a następnie ich realizacja $\mathrm{w}$ absolutnej zgodzie $\mathrm{z}$ uprzednio przyjętym projektem. Proces planowania i realizacji badań przebiega zawsze podobnie (por. rysunek 1), choć z uwagi na różnorodność firm i problemów decyzyjnych wszystkie podejmowane w jego ramach czynności badawcze muszą być każdorazowo dostosowane do ich specyfiki. Nie ma bowiem jednego uniwersalnego rozwiązania (w zakresie doboru próby do badania, wyboru metody zbierania danych czy instrumentów pomiarowych itp.) pasującego do wszystkich sytuacji. Nie ma też jednego pomysłu na badanie, które dostarczy wystarczającego zasobu wiedzy. Dane niezbędne do podjęcia ostatecznych decyzji należy zbierać z wielu źródeł (przy zastosowaniu rożnych metod i instrumentów), a następnie umiejętnie i efektywnie je łączyć i wykorzystywać.

26 Por. szczegółowy opis produktu na stronie firmy http://www.struga.pl/52-fosfill. html [dostęp: 20.06.2014]. 


\section{LITERATURA}

Anitsal I., Girard T., Anitsal M. M., (2012), An Application of Services Marketing Mix Framework: How do Retailers Communicate Information on Their Sales Receipts?, „Business Studies Journal”, Vol. 4, No. 2.

Bariery wspótpracy przedsiębiorców i ośrodków naukowych. Raport, (2006), MNiSW, Warszawa.

Bruner G. C., (1989), The Marketing Mix: Time for Reconceptualization, „Journal of Marketing Education”, Vol.11; DOI: http://dx.doi. org/10.1177/027347538901100212

Brzeziński J., (1984), Elementy metodologii badań psychologicznych, PWN, Warszawa.

Churchill G. A., (2002), Badania marketingowe. Podstawy metodologiczne, PWN, Warszawa.

Constantinides E., (2006), The Marketing Mix Revisited: Towards the 21st Century Marketing, ,Journal of Marketing Management”, Vol. 22, Issue 3/4;

DOI: ttp://dx.doi.org/10.1362/026725706776861190

Dymowski J., (2012), Dwa światy po dwóch stronach „,blękitnego oceanu”?, [w:] R. Karaszewski (red.), Społeczna odpowiedzialność biznesu, GoodBrand \& Company Polska, Warszawa.

English J. (2000), The Four “P”s of Marketing Are Dead, ,Marketing Health Services", Vol. 20, Issue 2.

Escher I., (2009), Marketingowa koncepcja, marketingowa orientacja czy rynkowa orientacja? O tych i innych nieporozumieniach wokót kluczowych terminów marketingowych, „Pieniądze i Więź”, nr 4.

Escher I., (2011a), Badania marketingowe, [w:] K. Andruszkiewicz (red.), Marketing. Podręcznik akademicki, Wydawnictwo „Dom Organizatora”, Torun.

Escher I., (2011b), Orientacja marketingowa i orientacja rynkowa jako efekt implementacji marketingu w organizacjach, [w:] K. Andruszkiewicz (red.), Marketing. Podręcznik akademicki, Wydawnictwo „Dom Organizatora”, Torun.

Escher I. (2011c), Wiedza, świadomość i postawa marketingowa pracowników przedsiębiorstw funkcjonujacych na terenie Polski, [w:] S. Kaczmarczyk, J. Petrykowska (red.), Stan i rozwój marketingu w przedsiębiorstwach funkcjonujacych na terenie Polski, „Handel Wewnętrzny”, wrzesień-październik.

Escher I., (2012a), Polski rynek nawozowy w opinii klientów Struga S.A. Raport z badania, Toruń 2012. 
Escher I., Łapińska J., (2014), Ocena atrakcyjności rynkowej wariantów nowego produktu z zastosowaniem analizy wielokryterialnej (na przykladzie nawozu fosforowego), artykuł zgłoszony na konferencję pt. Zachowania konsumentów a zarządzanie organizacjami (Międzyzdroje, 19-20.05.2014 r.), uzyskał pozytywne recenzje, oczekuje na publikację w czasopiśmie „Handel Wewnętrzny".

Garbarski L., Rutkowski I., Wrzosek W., (2000), Marketing. Punkt zwrotny nowoczesnej firmy, PWE, Warszawa.

Grönroos Ch., (1994), Quo Vadis, Marketing? Toward a Relationship Marketing Paradigm, „Journal of Marketing Management”, No.10; Issue 5

DOI: http://dx.doi.org/10.1080/0267257X.1994.9964283

Hague P., (2002), Badania marketingowe. Planowanie, metodologia i ocena wyników, Helion, Gliwice.

Identyfikacja i ocena barier $w$ aplikowaniu o środki w ramach funduszy strukturalnych przez jednostki naukowe i przedsiębiorców. Raport,(2008), ARC Rynek i Opinia, Warszawa.

Kaczmarczyk S., (1999), Zarzadzanie marketingowe a zarzadzanie marketingiem, [w:] J. Altkorn (red.), Kierunki rozwoju zarzadzania marketingowego $w$ Polsce. Raport z badań, Wydawnictwo AE w Krakowie, Kraków.

Kaczmarczyk S. (red), (2002), Zarzadzanie marketingowe $w$ polskich przedsiębiorstwach. Stan, zastosowanie, tendencje i kierunku zmian. Raport z badania, Wydawnictwo UMK, Torun.

Kaczmarczyk S., (2007), Zastosowania badań marketingowych. Zarzadzanie marketingowe i otoczenie przedsiębiorstwa, PWE, Warszawa.

Kaczmarczyk S., (2011), Badania marketingowe. Podstawy metodyczne, PWE, Warszawa.

Kaczmarczyk S., Petrykowska J. (red.), (2011), Stan i rozwój marketingu w przedsiębiorstwach funkcjonujacych na terenie Polski, „Handel Wewnętrzny”, wrzesień-październik.

Karwacka M., (2012), CSR - środek zaradczy na utrwalone bariery wspótpracy na linii biznes-nauka, [w:] R. Karaszewski (red.), Spoteczna odpowiedzialność biznesu, GoodBrand \& Company Polska, Warszawa.

Katalog PTBRiO 2007 (za rok 2006), XII edycja. Warszawa.

Katalog PTBRiO 2010/2011 (za rok 2009), XV edycja, Warszawa.

Maison D., (2010), Jakościowe metody badań marketingowych. Jak zrozumieć konsumenta, PWN, Warszawa.

Marciniak B., (2006), Dojrzewanie rynku badawczego, Katalog PBRiO 2006 (za rok 2005), ,Rynek Badań - Badacze - Firmy Badawcze”, XI edycja, Warszawa. 
Mazurek-Łopacińska K. (red), (2002), Badania marketingowe. Podstawowe metody i obszary zastosowań, Wydawnictwo AE we Wrocławiu, Wrocław.

Mynarski S., (2000), Praktyczne metody analizy danych rynkowych i marketingowych, Zakamycze, Kraków.

Rocznik PTBRiO 2012/2013 (za rok 2011), XVII edycja, Warszawa.

Rocznik PTBRiO 2013/2014 (za rok 2012), XVIII edycja, Warszawa.

Rószkiewicz M., (2002), Metody ilościowe w badaniach marketingowych, PWN, Warszawa.

Sierra Bravo R. (2008), Técnicas de Investigación Social. Teoría y ejercicios, Internacional Thomson Editores Spain Paraninfo, S.A., Madrid.

Szewczyk M., Ciesielska M., (2000), Podstawy statystyczne badań marketingowych, Oficyna Wydawnicza Politechniki Opolskiej, Opole.

Szreder M., (2010), Metody i techniki sondażowych badań opinii, PWE, Warszawa.

Waterschoot van W., Bulte van den Ch., (1992), The 4P Classification of the Marketing Mix Revisited, „Journal of Marketing”, Vol. 56, Issue 4; DOI: http:// dx.doi.org/10.2307/1251988

$\mathrm{http} / /$ struga.pl [20.06.2014]

http://struga.pl/52-fosfill.html [20.06.2014]

\section{MARKETING RESEARCH AS A BASIS FOR PLANNING MARKETING ACTIVITIES AND MARKETING INSTRUMENTS FOR LAUNCHING (THE CASE OF STRUGA COMPANY'S PHOSPHOROUS FERTILISER)}

Abstract: The paper presents the role of properly planned and conducted marketing research in organizations operating in a changing and turbulent environment. In the description the author refers to a research conducted for STRUGA COMPANY. Its main objective was to obtain data to support company management in planning marketing activities and marketing instruments for launching on the polish market the company's innovate fertiliser made of ash produced in the firm during the process of combustion the animal by-products.

K e y w ords : marketing; marketing research; marketing-mix; phosphorous fertilizer. 